\title{
Household preferences for municipal water services in Nicaragua
}

\author{
WILLIAM F. VÁSQUEZ \\ Department of Economics, Fairfield University, 1073 North Benson Road, \\ Fairfield, CT 06824, USA. Tel: 1-203-254-4000 x2363. Fax: 1-203-254-4074. \\ Email: wvasquez@fairfield.edu
}

DINA FRANCESCHI

Department of Economics, Fairfield University, USA. Email: dfranceschi@fairfield.edu

\author{
GERT T. VAN HECKEN \\ Institute of Development Policy and Management, University of Antwerp, \\ Belgium.Email: Gert.Vanhecken@ua.ac.be
}

Submitted July 20, 2010; revised February 8, 2011; accepted June 10, 2011; first published online 18 August 2011

\begin{abstract}
Choice models and a referendum format contingent valuation survey are used to investigate household preferences for improved water services and decentralization levels (actual departmental administration vs. further decentralization to the municipality) in urban Matiguás, Nicaragua. Choice models suggest that households prefer the current departmental administration over municipal provision for service and capacity, but believe that the municipality would be more interested in improving services. Results also indicate that households are willing to pay an increment of at least 112 per cent above their current monthly water bill for reliable and safe drinking water services, regardless of administration type.
\end{abstract}

\section{Introduction}

In spite of the significant amount of resources invested in water infrastructure and a variety of management reforms in the water sector, water supply is often unreliable and insufficient to satisfy the existing demand for safe drinking water in many developing countries (Soto Montes de Oca and Bateman, 2006; UNDP, 2006). Many water systems are caught in a low-level equilibrium trap with low operational efficiency, low service quality, low revenue and little incentive to change (Strand and Walker, 2005). System revenues are often not enough to adequately maintain water infrastructure, treat water for drinking purposes and extend water services to the poor (Olmstead, 2003). Consequently, water systems in developing countries are commonly unreliable and tap water is unsafe to drink (UNDP, 2006). 
Unreliable water systems have a negative impact on household welfare, and impose significant costs and distributional inefficiencies, particularly on poor households (Baisa et al., 2010). By providing unsafe-to-drink water, systems increase the prevalence of water-borne diseases and associated costs (e.g., work days lost and resources spent on health care). Diarrheal diseases alone, caused by unsafe water supply, fueled at least in part by poor sanitation and hygiene, lead to 1.5 million deaths per year, most of which are children particularly in developing countries (Prüss-Üstün et al. 2004). Households often adopt a number of averting measures to procure clean water such as private investments in water infrastructure, treatment of water at home (e.g., water boiling and filtering) and consumption of bottled water (Pattanayak et al., 2005; Vásquez et al., 2009). Some of these measures may be expensive, particularly the purchase of bottled water which is substantially more expensive than tap water (Ferrier, 2001; Blaurock-Busch, 2009). Water treatment at home is also often not cost effective (Goodrich et al., 1992). Hence, poor households are less able to cope with unreliable water systems.

In academic and policy circles alike, decentralization of water services, in which the responsibility of water provision is shifted from the national or state (departmental) level to the local government, has often been proposed. It is suggested as a way to increase efficiency and equity in the water sector, mainly because local governments are expected to have better knowledge of local water demand and have more direct political incentives and accountability to efficiently use available resources (World Bank, 2003). ${ }^{1}$ However, decentralization has not always improved the efficiency of service providers. In India, for example, Asthana (2003) found that locally managed water utilities are less efficient than state-managed water utilities in terms of expense and asset utilization. Anwandter and Ozuna (2002) also report that the decentralization of water services to the municipal level has not improved the efficiency of water utilities in Mexico. The optimal level of decentralization is still widely debated given that local governments often lack the technical, financial and administrative capacity needed to provide water services (Bardhan, 2002; Larson, 2002; Ahmad et al., 2005).

Decentralization initiatives also seem to be susceptible to local elite capture, limited financial support at the local level (sometimes called 'unfunded mandates') and limited confidence in the administrative capacity of the local government (Bardhan and Mookherjee, 2000; Ahmad et al., 2005; Rouse, 2007). Public demand for (de)centralized services may also affect decentralization outcomes, given that local preferences can impact the legitimacy of local governments (Rodríguez-Pose et al., 2009). Thus, potential benefits from decentralizing public services seem to depend, to a certain extent, on the government level at which public services

${ }^{1}$ Other reforms have also been proposed to escape the inefficiency of centralized services, including privatization, concessions, public-private partnerships, and community-based approaches (Isham and Kahkonen, 2002; Prasad, 2006). 
are decentralized and on the public preferences for such decentralization initiatives.

However, local preferences are often neglected in decentralization initiatives, especially as these initiatives are often characterized as topdown processes instigated by national governments in response to political pressures, rather than national, inclusive development planning (Rojas, 2000). By ignoring local preferences, public opposition to decentralization initiatives may be exacerbated, and expected outcomes may not be delivered. In the particular case of water services, lack of information on household preferences concerning potential improvements has been identified as an important obstacle to the implementation of reliable water systems (World Bank, 1993). Understanding household preferences may help identify the needs of citizens by revealing their preferred level of service, as well as the supplier they think is most likely to deliver improved water services. This would be of particular policy relevance for places where decentralization of water services has taken place in some locations and is being planned for others, such as in Nicaragua (see CONAPAS, 2005).

This paper uses choice models and split-sample contingent scenarios to investigate household preferences for improved water services and decentralization levels in urban Matiguás, Nicaragua. The analysis is timely and relevant as the water sector is an integral component of the national decentralization initiative currently taking place in Nicaragua (CONAPAS, 2005). Results indicate that households are willing to pay an increment of at least 112 per cent above their current monthly water bill (equivalent to 4 per cent of household income) for reliable and safe drinking water services. Estimated models of willingness to pay (WTP) suggest that households are indifferent to the level of decentralization. Choice models, however, indicate that households are slightly more likely to choose the current departmental administration over municipal provision in terms of potential service quality, awareness of water issues and capacity. In contrast, choice models suggest that most households believe that the municipality would be more interested in improving water services. Reported satisfaction from current water services seems to be the main determinant of such household beliefs regarding decentralization initiatives.

The rest of the paper is organized as follows. Section 2 describes the context in which the study was conducted and the conditions of actual water services in Matiguás. The survey design is presented in section 3. Section 4 introduces the analytical framework and econometric methods used to estimate household preferences for improved water services and for decentralization levels. Section 5 presents the empirical results. Section 6 discusses the results and concludes the paper.

\section{Background and current water supply in Matiguás}

The municipality of Matiguás is located in the department of Matagalpa, at a distance of $140 \mathrm{~km}$ northeast of the Nicaraguan capital city of Managua. In 2005, the total population of Matiguás was estimated at 41,127 people, with about 9,000 living in the urban center in 2,309 houses (INIDE, 
2005). Despite steady economic development in recent years, the municipality is still part of a region with a high degree of poverty where 25.8 per cent of citizens live in poverty, and an additional 59.1 per cent live in extreme poverty. ${ }^{2}$ Life expectancy is about 65.5 years and though gains have been made during the last few years, at 41.5 per cent, the illiteracy rate in the region is still one of the highest in Nicaragua (Levard et al., 2001; INIDE, 2005).

Most of the soil in Matiguás is considered to have a low natural permeability level, with a low water infiltration capacity. Cattle ranching and agricultural practices, which are the region's main economic activities, have resulted in high deforestation rates. According to local estimations, during the last 20 years approximately 40 per cent of the forested area in Matiguás has been cut down (Van Hecken and Bastiaensen, 2009). As such, the advancement of the agricultural frontier, with transformation of forested areas into pastures for extensive cattle ranching, has further lowered the water infiltration capacity of the region. As a consequence, it is increasingly difficult to maintain an adequate level of groundwater, which has resulted in rivers partly running dry during the dry season and in uncontrolled surface water increases (inundations) during the rainy season. Inappropriate agricultural practices also pollute fresh water sources with agrochemicals and other contaminants. In addition to the aforementioned, iron and arsenic were also found in groundwater samples taken at several sites in the department of Matagalpa (PAHO and ENACAL, 2004).

Matiguás obtains its water from the Cusiles River, which originates in the protected area of the Sierra Quirragua (northwest of Matiguás). At a distance of about $4 \mathrm{~km}$ from the urban center, water is captured through a system of filtration wells next to the river. The filtered water is then pumped to a decompression tank, after which it flows towards the supply tanks in the urban center. Increasing population pressures during the last 20 years emphasized the need for service and capacity expansion. In 2004 the system was modernized, including new filtration wells, tanks and pipes at a cost of approximately US $\$ 1$ million, partly subsidized by the centralized water company ENACAL (Nicaraguan Company of Water and Sanitation), and partly by a German development bank (KfW). Despite these investments, the system today still shows several flaws and water supply strongly varies in continuity, with reported service interruptions that could last up to several days. Interruptions are more common and longer in the rainy season because the system is shut off as river currents and turbidity are often beyond the capacity of the filtration wells. Tap water is treated with chlorine, but it is not treated for chemical residuals and heavy metals that seem to be common in the area (PAHO and ENACAL, 2004).

The water supply service in Matiguás is administered by the Water Utility of Matagalpa (AMAT) at the departmental level. AMAT was established in 2000 as part of a public service decentralization process. However,

2 Please consult http://www.inide.gob.ni/censos2005/CifrasMun/Definiciones.htm for more information on the definition and characterization of poverty levels. 
AMAT is not completely independent from the national ENACAL which administers the majority of water systems in Nicaragua. ENACAL assists AMAT in several managerial, financial and technical issues (PAHO and ENACAL, 2004). AMAT is constrained by the inability to set its own water tariffs given that the regulatory Nicaraguan Institute of Water and Sanitation (INAA) has to approve all water tariffs charged by any supplier in Nicaragua (Arze and Martinez-Vazquez, 2004). So far, INAA has been unable to adjust water tariffs to recover operation and maintenance costs. As a consequence, water utilities in Nicaragua, including AMAT, generally operate under growing financial deficits (PAHO and ENACAL, 2004; World Bank, 2008).

The 2005-2015 National Drinking Water Strategy deems decentralization a fundamental element for the development and improvement of water services across the country (CONAPAS, 2005). Also, within the framework of the Nicaraguan Policy of Decentralization Oriented to Local Development (Decree No. 45-2006), a number of recent laws aim to facilitate the decentralization of public services and strengthen the autonomy and capacity of municipalities. ${ }^{3}$ For instance, Article 7 of the Municipality Law assigns the responsibility for providing water services to municipalities, including building, operating and maintaining water infrastructure. In practice, however, only 26 (out of 152) Nicaraguan municipalities have taken up the administration and operation of urban water systems (CONAPAS, 2005), presumably because expansion of municipal responsibilities has not been properly accompanied by a sufficient increase in budget transfers from the central to the municipal level (see Rosales and Valencia Carmona, 2008). Some Nicaraguan municipalities such as Matiguás, however, are still discussing the option of improving obsolete centralized water services and are considering taking up the responsibility of providing water services to their citizens in a decentralized form. Budget and transfer constraints oblige these municipalities to focus on potential local funds, and thus local demand for making the project sustainable. WTP valuations could help elicit the existence and availability of the local demand and funds. Furthermore, improved understanding of household preferences may provide important inputs to the planning process by identifying the preferred level of decentralization in the water sector and the quality of water services that citizens demand (Bingham, 2006).

\section{Survey design}

Surveys aimed to elicit a respondent's preferences require careful survey design, choice of survey mode, and selection of a random sample (Whittington, 2002). Careful design of studies implemented in developing countries is particularly important given that misleading information provided during the interview may motivate respondents to adopt behaviors

3 The Municipal Budget Regime, Civic Participation, Financial Transfers, and Municipal Fiscal Solvency Acts were established between 2002 and 2004 (Rosales and Valencia Carmona, 2008). 
that could harm themselves and can negatively impact the policy process (Whittington, 2004). The survey implemented in this study was carefully designed based on several months of qualitative research, three focus group interviews, several pilot surveys implemented in the field by locally trained interviewers and a number of iterations to incorporate feedback. In-person interviews were conducted in August 2009. A geographically stratified random sampling strategy was used to select the households to be interviewed from a list of 1,955 households connected to the water system. A total of 1,015 surveys were completed at a response rate of 74.5 per cent. No evidence on systematic non-responses was found. The final version of the survey elicited household responses on the current water system, water uses and practices, households' expenditures on both tap and bottled water, and socio-demographic characteristics.

In order to investigate household preferences for decentralization levels, respondents were also confronted with the hypothetical proposal below to decentralize water services to the municipal level in which the provider was the only system attribute changed:
Currently, the water service is administrated by the Water Utility of Matagalpa (AMAT). Suppose that the municipality of Matiguás has the opportunity to administer the water service. This implies the creation of a municipal water utility, which will be responsible for administering the service and maintaining the drinking water system. The revenue collected from water tariffs would be used by the municipality of Matiguás to maintain and manage the water system of Matiguás exclusively.

Then, respondents were asked to choose between the current departmental provider AMAT and the municipality in terms of institutional characteristics that can affect decentralization outcomes including: (1) the service quality that these institutions would provide; (2) these institutions' knowledge of water problems in the city; (3) capacity to solve those problems; (4) interest in solving them, and (5) the amount of resources that they would invest in the water system. Respondents' choices between these institutions reveal household preferences for decentralization levels, and can point to potential impediments to expected decentralization outcomes (see Ahmad et al., 2005; Rouse, 2007).

While choice questions may depict household preferences for different levels of decentralization, it can be argued that people would accept such administration change only if it comes with improvements of water services. Thus, a subsample of 508 households was randomly confronted with a contingent valuation (CV) scenario in which current water services are improved by implementing specific infrastructural improvements. Despite a variety of validity and measurement issues (see recent reviews in Carson and Hanemann, 2006 and Carson and Groves, 2007), CV surveys have proved to be a viable method for collecting information on preferences for public goods and services in developing countries (Whittington, 1998). Rosado et al. (2006) and Vásquez et al. (2009) provide recent examples of CV studies used to elicit household preferences (i.e., WTP) for improved water services in Brazil and Mexico, respectively. 
In the CV scenario, households were told that the improved service would provide safe drinking water at the tap, 24 hours a day, every day of the year, and with no interruptions. In order to further investigate the decentralization level that households prefer, the experimental design also included a split-sample treatment with variations in the administration level of the proposed improved water system: (a) the current administrator at the departmental level (i.e., AMAT), and (b) the municipality of Matiguás. Finally, households were told that in order to finance the proposed service, every household would have to pay an additional monthly fee for the improved water service that was randomly varied across sample households taking values between 20 to 180 Nicaraguan Cordobas (C\$), with an interval of $C \$ 20 .{ }^{4}$ The referendum voting question presented in the survey is as follows:

Keep in mind that the current water service in Matiguás is frequently interrupted and that water is sometimes unsafe to drink. Suppose that the Matiguás residents would have the opportunity to vote in favor of or against a project that would improve the current tap water service. The project would consist of replacing the current pumps, filters, and purification system with more advanced technology to collect and treat water from the river Cusiles. The new system would collect more water, and would treat the water in order to reduce the levels of chemicals and residuals from farmers and communities upstream. Therefore, with the new system, you will have tap water that will be totally safe to drink and with good pressure 24 hours per day, every day of the year, and without any interruptions. CURRENT DECENTRALIZATION LEVEL: [The new system would be administered by the current Water Utility of Matagalpa.] FURTHER DECENTRALIZATION: [Furthermore, as part of the project, the water service administration would be transferred to the municipality by creating a municipal water utility to be administered by the municipality of Matiguás to locally operate the water system.] However, this project would cost money. In order to finance the project, it would be necessary to increase the water bill of all water users in Matiguás. Your water bill would increase by an amount of C\$ FEE per month, in addition to what you currently pay. Keep in mind that the increment of C\$ FEE per month that you would pay for the improved water service will not be available to purchase other things such as groceries, clothes and other items needed in your household.

Would you vote in favor of or against the project? _ Yes (in favor of the project) __ No (against the project)

Champ et al. (1997), Blumenschein et al. (2008) and Morrison and Brown (2009) argue that potential biases of WTP estimates derived from the hypothetical nature of the $\mathrm{CV}$ method can be reduced and that WTP for a

4 The official exchange rate as of August 2009 was C $\$ 20.42 /$ US $\$ 1$. 
non-market good can be precisely estimated by using information collected through follow-up certainty questions (see Carson and Hanemann (2006) for a discussion of hypothetical bias of CV estimates). Recent studies use this approach to mitigate hypothetical bias by coding favorable responses as such only if reported certainty levels surpass a given threshold of certainty using 0-10 and 0-100 scales (e.g., Vossler et al., 2003; Groothuis et al., 2007; Vásquez et al., 2009). During focus groups and pilot interviews, it was discovered that the majority of respondents did not understand or were very confused when the number-scaled certainty approach was used. Therefore, a discrete, four-tiered scale ranging from 'Very Uncertain' to 'Very Certain' was implemented to measure response certainty and thus compute more conservative WTP estimates.

\section{Analytical framework and modeling approach}

\subsection{Choice models}

The survey data include respondents' choices between the municipality and the current system administration in terms of service quality, how much they would invest in water infrastructure, and these institutions' knowledge, capacity and interest regarding water issues in the city. Respondents are assumed to choose between these institutions based on their preferences for further decentralization of water services. Under the assumption that such preferences follow a linear form (i.e., $Z \delta+\varepsilon$ ), respondents' choices can be represented using a binary indicator (MUNIC) as follows:

$$
M U N I C= \begin{cases}1, & \text { if } Z \delta+\varepsilon>0 \\ 0, & \text { if } Z \delta+\varepsilon \leq 0\end{cases}
$$

where $Z$ is a vector of covariates, $\delta$ is the vector of coefficients to be estimated, and $\varepsilon$ is the stochastic error assumed to follow a logistic distribution. The probability that a respondent would choose to further decentralize water services at the municipal level over the status quo is expressed as follows:

$$
P(M U N I C=1)=\frac{1}{1+\exp (-Z \delta)}
$$

Table 1 shows the definition and descriptive statistics of the covariates included in vector $Z$. The variable SERVRATE is included to measure the effect of perceptions of the quality of current water services on the probability of supporting further decentralization. This effect is expected to be negative (i.e., $\delta_{S E R V R A T E}<0$ ) given that public support for the municipality as the potential water provider is expected to be lower if current water services are perceived to be of good quality. The consumption of bottled water (BOTWAT) is also included, given that households that purchase bottled water may perceive that tap water is unsafe to drink. These households may be more likely to support further decentralization if they expect that the municipality will provide a less expensive substitute for bottled water (i.e., $\delta_{\text {BOTWAT }}>0$ ). Other respondent and household 
characteristics included are AGE, FEMALE, EDUC, INCOME, HHSIZE and OWN (see table 1).

\subsection{WTP models}

Responses to referendum questions can be analyzed using a utilitytheoretic framework. Initial indirect utility of a household is represented

Table 1. Variables included

\begin{tabular}{|c|c|c|c|}
\hline Variables & Definition & $\begin{array}{l}\text { HHPref } \\
\text { Mean (S.D.) }\end{array}$ & $\begin{array}{l}\text { WTP } \\
\text { Mean (S.D.) }\end{array}$ \\
\hline SERVRATE & $\begin{array}{l}\text { Subjective perception of the overall } \\
\text { service quality on a } 5 \text { point scale } \\
(1=\text { very bad, } 2=\text { bad, } 3=\text { regular, } \\
4=\text { good, } 5=\text { very good })\end{array}$ & $2.89(0.72)$ & - \\
\hline BOTWAT & $\begin{array}{l}\text { If the household currently con- } \\
\text { sume bottled water }(1=\text { Yes, } \\
0=\text { Otherwise })\end{array}$ & $0.46(0.50)$ & - \\
\hline INCOME & $\begin{array}{l}\text { Household's income grouping in } \\
\text { Cordobas }(0=\text { no income, } 1=\text { less } \\
\text { than } 1,000,2=1,001-2,000 \\
3=2,001-3,000,4=3,001-4,000 \\
\ldots 11=10,001-15,000,12=\text { more } \\
\text { than } 15,000)\end{array}$ & $3.36(2.54)$ & $3.37(2.43)$ \\
\hline AGE & Age of respondent (in years) & $39.09(13.94)$ & $38.24(13.78)$ \\
\hline FEMALE & $\begin{array}{l}\text { Sex of respondent }(1=\text { Female } \\
0=\text { Male })\end{array}$ & $0.75(0.43)$ & $0.75(0.43)$ \\
\hline EDUC & $\begin{array}{l}\text { Education of respondent (in years } \\
\text { of schooling) }\end{array}$ & $7.24(4.50)$ & $7.08(4.50)$ \\
\hline OWN & $\begin{array}{l}\text { If the respondent household is } \\
\text { owner of the house }(1=\text { Yes, } \\
0=\text { Otherwise })\end{array}$ & $0.88(0.32)$ & $0.88(0.33)$ \\
\hline HHSIZE & Number of household's members & $4.80(2.29)$ & $4.73(2.12)$ \\
\hline VOTE & $\begin{array}{l}\text { If the respondent voted in } \\
\text { favor of the project }(1=\text { Yes, } \\
0=\text { Otherwise })\end{array}$ & & $0.61(0.49)$ \\
\hline VOTESURE & $\begin{array}{l}\text { If the respondent voted in favor } \\
\text { of the project and reported to } \\
\text { be certain about her response } \\
(1=\text { Yes, } 0=\text { Otherwise })\end{array}$ & - & $0.51(0.50)$ \\
\hline LNFEE & $\begin{array}{l}\text { Natural logarithm of the additional } \\
\text { fee charged for water service } \\
\text { improvement in the CV question }\end{array}$ & - & $4.40(0.68)$ \\
\hline CITY & $\begin{array}{l}\text { Institution to administer the } \\
\text { improved water service in the } \\
\text { CV question ( } 1=\text { Municipality, } \\
0=\text { current provider AMAT) }\end{array}$ & - & $0.51(0.50)$ \\
\hline TAPDRINK & $\begin{array}{l}\text { If household's members drink tap } \\
\text { water without treating it }(1=\text { Yes, } \\
0=\text { Otherwise })\end{array}$ & - & $0.76(0.43)$ \\
\hline
\end{tabular}


Table 1. Continued

\begin{tabular}{|c|c|c|c|}
\hline Variables & Definition & $\begin{array}{l}\text { HHPref } \\
\text { Mean (S.D.) }\end{array}$ & $\begin{array}{l}\text { WTP } \\
\text { Mean (S.D.) }\end{array}$ \\
\hline FEASIBLE & $\begin{array}{l}\text { If the respondent thought that } \\
\text { the proposed project could } \\
\text { be implemented in Matiguás } \\
\text { ( } 1=\text { Yes, } 0=\text { Otherwise })\end{array}$ & - & $0.84(0.37)$ \\
\hline HOURS & $\begin{array}{l}\text { Number of hours with water service } \\
\text { per day during the summer }\end{array}$ & - & $14.37(9.01)$ \\
\hline QUALRATE & $\begin{array}{l}\text { Subjective perception of tap } \\
\text { water quality on a } 5 \text {-point scale } \\
(1=\text { very bad, } 2=\text { bad, } 3=\text { regular, } \\
4=\text { good, } 5=\text { very good })\end{array}$ & - & $3.00(0.73)$ \\
\hline
\end{tabular}

by the function $V\left(Y, W_{C}, P, H\right)$ where $Y$ represents household income, $W_{C}$ represents current water services, $P$ stands for prices of other goods and $H$ is a set of relevant household characteristics. The indirect utility is positively related to income and water services, and negatively related to prices of other goods (i.e., $V_{Y}>0, V_{W C}>0, V_{P}<0$ ). This theoretical model would predict that households will be willing to pay for improved water services $\left(W_{I}\right)$ up to the extent that this improvement compensates for the loss in utility derived from such payment:

$$
V\left(Y, P, W_{C}, Z\right)=V\left(Y-W T P, P, W_{I}, Z\right)
$$

Therefore, WTP is a function of attributes of water services, income, prices of other goods and household characteristics. In this study, the WTP function is assumed to follow a log-linear form:

$$
L N W T P=X \beta+e
$$

where LNWTP represents the natural logarithm of households' willingness to pay for a change in water services. $X$ is a vector of covariates including a treatment variable (indicating different levels of decentralization), household income and other relevant household characteristics. $\beta$ is a vector of coefficients to be estimated, and $e$ is the stochastic error term.

The referendum approach used in this study does not allow for direct observation of WTP for improvements of water services. However, LNWTP can be indirectly identified given that respondents are expected to provide a favorable answer to the referendum voting question only if the household's WTP is greater than or equal to the fee presented in the contingent scenario. Thus, under the assumption that the stochastic error term in equation 4 follows a logistic distribution, the following equivalence 
is obtained: ${ }^{5}$

$$
P(\text { Vote }=Y e s)=P(e / K \geq L N F E E / K-X \beta / K)
$$

The maximization of the corresponding likelihood function directly provides estimates for $\beta$ coefficients even though LNWTP is not directly observed (Cameron, 1988). Equation (4) is estimated following this approach.

Information obtained through a follow-up certainty question is used to recode responses to the referendum question and thus compute more conservative and presumably realistic estimates of households' WTP for improved water services (Blumenschein et al., 2008; Morrison and Brown, 2009; Vossler et al., 2003). The vote is assumed to be favorable (Vote $=$ Yes) only if the respondent voted in favor of the project and reported to be certain or very certain about her vote. If respondents report to be uncertain or very uncertain about their response, favorable votes are recoded as against the project. The equivalence reported in equation (5), and the logistic distribution of the error term, are assumed to hold. Thus, equation (4) is also estimated using the recoded answers.

Table 1 shows the definition and descriptive statistics of covariates (i.e., $X$ ) used to estimate equation (4). This vector includes the binary indicator CITY to depict differences in households' WTP for improved water services under different decentralization levels according to the split-sample experimental design. This indicator takes value one if respondents are told that the municipality would administrate the improved system, and zero otherwise. The estimated coefficient of CITY is expected to be positive if households favor further decentralization at the municipality level over the current departmental administration (i.e., $\beta_{\text {CITY }}>0$ ), and negative if the opposite is true (i.e., $\beta_{C I T Y}<0$ ).

The variable INCOME is also included, given that the theoretical framework assumes that reliable, safe drinking water is a normal good (i.e., $\beta_{I N C O M E}>0$ ) (see Whitehead, 1995). Households that perceive a smaller improvement from the current water system are expected to report a lower WTP. Thus, the variables HOURS, TAPDRINK, and QUALRATE are included to control for attitudes and perceptions on the system reliability and water quality. These variables are expected to have a negative impact on the household's WTP for improved water services (i.e., $\beta_{\text {HOURS }}<0$, $\beta_{\text {TAPDRINK }}<0$, and $\left.\beta_{\text {QUALRATE }}<0\right)$. In contrast, households that believe that the project is plausible are expected to report a higher WTP (i.e., $\beta_{\text {FEASIBLE }}>0$ ) given that they may also believe that the survey will have policy consequences and therefore tend to report higher WTP (Herriges

5 The probability of favorable responses is equal to the probability that LNWTP is greater than or equal to the natural logarithm of the fee presented to respondents in the referendum question $(L N F E E)$. That is, $\mathrm{P}($ Vote $=$ Yes $)=\mathrm{P}(L N W T P>$ $L N F E E)=\mathrm{P}(X \beta+e>L N F E E)=\mathrm{P}(e>L N F E E-X \beta)$. The assumption that the error term follows a logistic distribution allows for scaling the error term using a parameter $K$ that is related to the standard deviation (S.E.) of the error term (i.e., $\left.K=\sigma_{e} \sqrt{3} / \pi\right)$. 


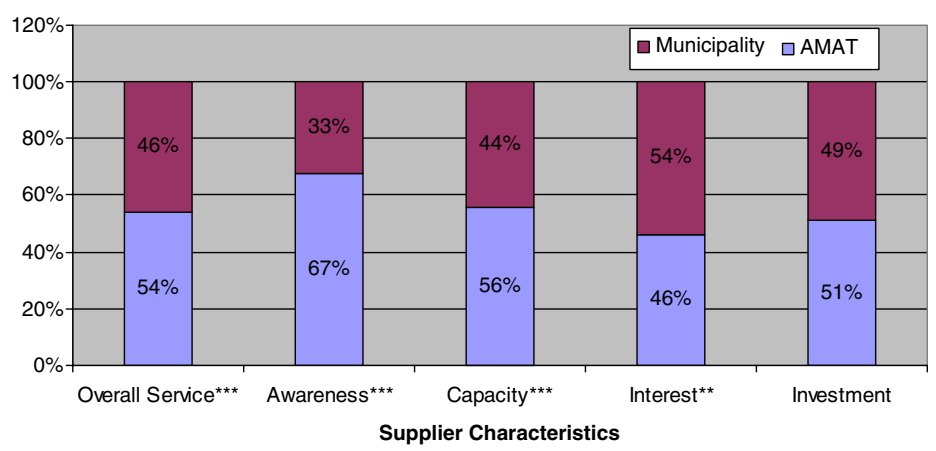

Figure 1. Household preferences for tap water supplier.

Note: ${ }^{* *},{ }^{* *}$ imply significance at $1 \%$ and $5 \%$ levels respectively.

et al., 2010). Other household characteristics included are AGE, FEMALE, EDUC, OWN, and HHSIZE. No specific hypotheses are made on the effect of these characteristics on WTP for improved water services.

\section{Empirical results}

Based on households' perception of both institutions' overall service quality, awareness of water issues, and capacity to solve such issues, figure 1 shows that a majority of households favor current departmental water services over further decentralization to the municipal level. This preference for departmental provision of water services is statistically significant (at 1 per cent level) based on binomial tests. According to these findings, public perceptions in Matiguás disagree with the argument that decentralization of services to the local government level will provide better knowledge of local water demand (see Asthana, 2003). Moreover, public perceptions support the argument that local governments lack the capacity needed to provide public services (see Bardham, 2002). Interestingly, figure 1 also indicates that a majority of households (significant at 5 per cent level) believe that the municipality would be more interested in solving water problems, which may facilitate water service decentralization to the municipality. Respondents seem to be divided when asked which institution, AMAT or the municipality, they think would invest more resources in solving water problems, with no statistical advantage for any institution.

Table 2 shows logit models estimated to identify the determinants of household choices. Results are consistent across choices in terms of signs and significance. Two factors seem to be the main determinants of household preferences for decentralization levels: SERVRATE and BOTWAT. Negative and significant coefficients on SERVRATE indicate that households that perceive a lower quality of water services are more likely to choose the municipality over the current departmental utility (AMAT). Similarly, households that consume bottled water would prefer municipal services over current departmental administration. These households may perceive the water system to be unreliable and unable to provide 
Table 2. Models of household preferences for municipal water services

\begin{tabular}{|c|c|c|c|c|c|}
\hline Variables & SERVICE & AWARENESS & САРАCITY & INTEREST & INVESTMENT \\
\hline SERVRATE & $-0.100(0.027)^{* * *}$ & $-0.078(0.022)^{* * *}$ & $-0.093(0.026)^{* * *}$ & $-0.099(0.027)^{* * *}$ & $-0.058(0.026)^{* *}$ \\
\hline $\mathrm{AGE}$ & $0.004(0.001)^{* *}$ & $0.005(0.001)^{* * *}$ & $0.002(0.001)$ & $-0.003(0.001)^{*}$ & $-0.0004(0.001)$ \\
\hline FEMALE & $-0.068(0.043)$ & $-0.057(0.038)$ & $-0.034(0.041)$ & $-0.074(0.041)^{*}$ & $-0.043(0.042)$ \\
\hline EDUC & $-0.002(0.005)$ & $0.009(0.004)^{* *}$ & $-0.004(0.005)$ & $0.004(0.005)$ & $-0.004(0.005)$ \\
\hline INCOME & $0.008(0.008)$ & $-0.0002(0.007)$ & $0.0001(0.008)$ & $0.009(0.008)$ & $0.006(0.008)$ \\
\hline HHSIZE & $-0.008(0.008)$ & -0.007 (0.007) & $-0.004(0.008)$ & $-0.012(0.008)$ & $-0.003(0.008)$ \\
\hline OWN & $0.018(0.060)$ & -0.007 (0.053) & 0.001 (0.059) & $-0.047(0.060)$ & $0.018(0.060)$ \\
\hline BOTWAT & $0.102(0.038)^{* * *}$ & $0.069(0.034)^{* *}$ & $0.118(0.037)^{* * *}$ & $0.080(0.037)^{* *}$ & $0.106(0.038)^{* * * *}$ \\
\hline Predicted prob & 0.431 & 0.310 & 0.427 & 0.530 & 0.482 \\
\hline Observations & 753 & 807 & 796 & 805 & 772 \\
\hline Log likelihood & -495.11 & -484.49 & -528.14 & -537.75 & -526.14 \\
\hline $\mathrm{AIC}$ & 1008.22 & 986.99 & 1074.28 & 1093.49 & 1070.28 \\
\hline $\mathrm{BIC}$ & 1049.84 & 1029.23 & 1116.4 & 1135.71 & 1112.12 \\
\hline Pseudo $\mathrm{R}^{2}$ & 0.039 & 0.041 & 0.029 & 0.034 & 0.016 \\
\hline
\end{tabular}

Notes: ${ }^{* *},{ }^{* *},{ }^{*}$ imply significance at $1 \%, 5 \%$ and $10 \%$ levels respectively. Numbers in parentheses are corresponding S.E. 
safe drinking water, and may consider changing the water provider as an initial step towards water system improvements. Findings also suggest that people with more education tend to believe that the municipality is better informed on local water issues. Similarly, the probability of choosing the municipality in terms of service quality and awareness increases with $A G E$. It may be speculated that older respondents have accumulated dissatisfaction from low quality services. Dissatisfied water users are expected to choose the municipality in hope of obtaining better services. Older respondents, however, seem to believe that the municipality would be less interested than the current provider in solving their water problems, and so do FEMALE respondents, presumably because the municipality has not attempted to undertake the water system administration until now. Other characteristics seem to have no effect on household preferences for decentralization levels. ${ }^{6}$

Household preference for improved water services are also investigated using the CV method. Table 3 shows six models of WTP for reliable and safe drinking water estimated using the information elicited through the referendum voting question. Models 1 through 3 provide different specifications of equation (2) based on the raw response to the voting question. Models 4 through 6 follow the same specifications as Models 1 through 3 respectively, but using the recoded responses according to the reported certainty levels on the referendum voting question. A total of 35 favorable votes (out of 245) are recoded as against the project given that respondents report being unsure or very unsure regarding their answer to the referendum question. A considerable degree of robustness is observed across all models in terms of signs and significance of the explanatory variables. However, these models yield different estimates of WTP.

The estimated coefficients on CITY are negative in all models as would be the case when households prefer water services to be administered at the department level. However, those coefficients are statistically insignificant which suggest that households are indifferent regarding the level of decentralization. Similarly, household income seems to have no effect on WTP for improved water services as estimated coefficients on INCOME are significant only in Models 1 and 4 (at 10 per cent significance level). The income effect becomes insignificant after controlling for other determinants. Earlier CV studies with similar findings argue that income is not a binding constraint given that the actual price for improved water services is small relative to household income (e.g., Casey et al., 2006). Households may also perceive the price for improved water services to be small relative to current indirect costs of low quality services (e.g., work days lost, expenditures on health care and averting costs).

Households that believe that project implementation is feasible in Matiguás report a higher WTP for improvements of the water system as

6 These results are robust across different specifications of choice models, including estimations containing other variables such as the amount paid by households in their last water bill, whether they drink tap water, and the time that respondents have lived in Matiguás. All of these variables were found to be statistically insignificant. Results are available upon request. 
Table 3. Estimated willingness to pay (WTP) models

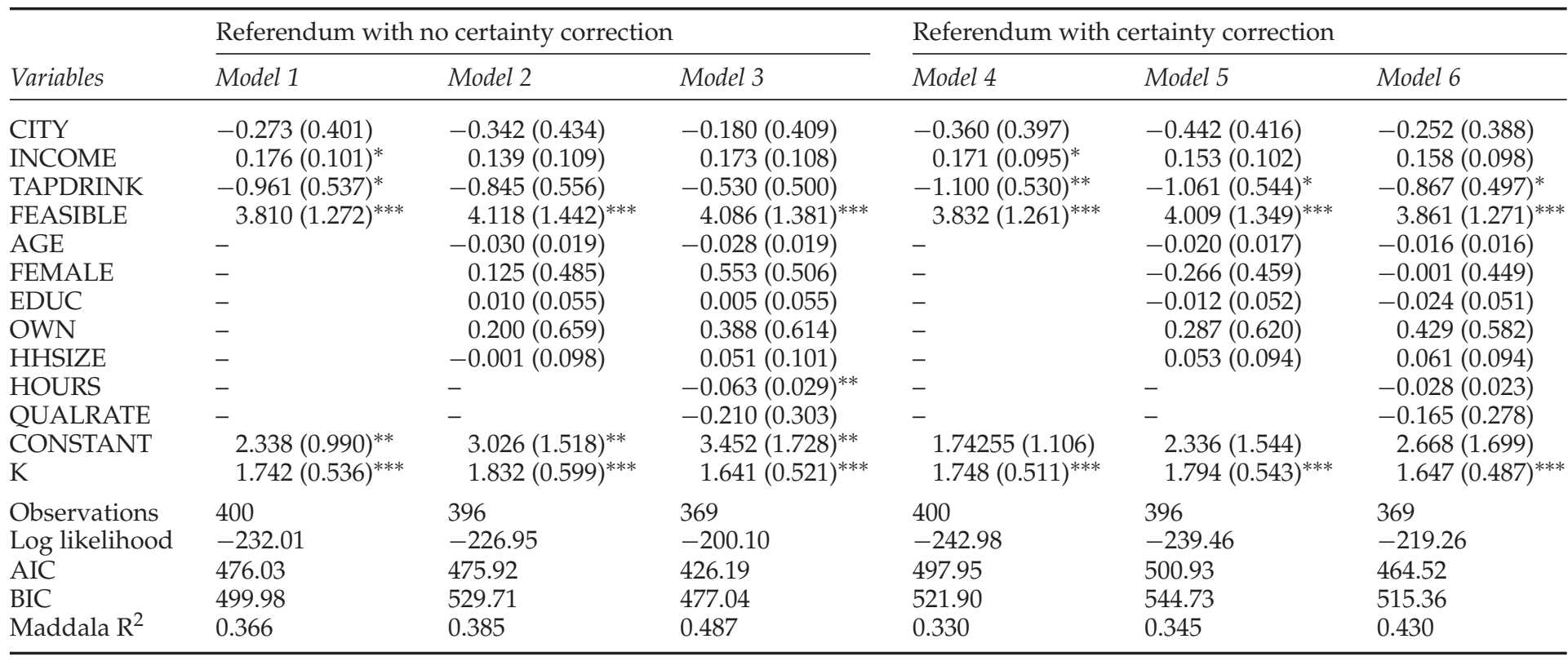

Notes: $* * *, * *$, imply significance at $1 \%, 5 \%$ and $10 \%$ levels respectively. Numbers in parentheses are corresponding S.E. 
indicated by positive and significant coefficients of FEASIBLE in all models. This result is consistent with the hypothesis that respondents who believe that the survey will have real policy consequences tend to report higher WTP (Herriges et al., 2010). Also, the sign and significance of parameter $K$ in all models indicates that respondents are sensitive to the price, which provides evidence on construct validity of the contingent scenario (Cameron, 1988; Whitehead, 1995).

It was expected that households that perceive a smaller system improvement would report a lower WTP for the proposed improvement. That seems to be the case for those households that report to drink tap water without treating it in four (out of six) models. Those households may drink tap water because they perceive that it is of good quality or because they are risk takers. In both cases, the proposed project to improve water quality will imply a smaller improvement and, therefore, lower WTP for such improvement. Given that the contingent scenario also includes system reliability improvements, the variable HOURS is included in Models 3 and 6. The corresponding coefficient is significant only in Model 3. While this finding suggests that households with fewer hours of service are willing to pay more for the proposed system improvement, the evidence is not conclusive. Similarly, insignificant coefficients are found for households' satisfaction from water quality (QUALRATE). Other respondent and household characteristics (i.e., AGE, FEMALE, EDUC, OWN and HHSIZE) also seem to have no effect on WTP for improvements of the water system.

Estimated models are also used to compute households' willingness to pay for improved water services. Table 4 shows those WTP estimates and their corresponding 95 per cent confidence intervals calculated using Krinsky and Robb's (1986) boot-strapping procedure with 5,000 simulations. Estimates based on Models 1 through 3 (uncorrected for certainty on responses) indicate that households are willing to pay a significant increment for improved water services, between $\mathrm{C} \$ 189.16$ and $\mathrm{C} \$ 216.84$ (US\$9.26-10.62). That increment is equivalent to more than 200 per cent above current water bills, and approximately 9 per cent of reported

Table 4. WTP estimates with corresponding confidence intervals

\begin{tabular}{lrllll}
\hline & Median & $\begin{array}{l}\text { 95\% CI } \\
\text { lower } \\
\text { bound }\end{array}$ & $\begin{array}{l}\text { 95\% CI } \\
\text { upper } \\
\text { bound }\end{array}$ & $\begin{array}{l}\text { Median WTP in } \\
\text { relation to } \\
\text { household } \\
\text { income }(\%)\end{array}$ & $\begin{array}{l}\text { Median WTP in } \\
\text { relation to current } \\
\text { tap water } \\
\text { expenditure }\end{array}$ \\
\hline Model 1 & 189.16 & 102.40 & 350.43 & 8.57 & 236.45 \\
Model 2 & 202.88 & 102.61 & 405.90 & 9.19 & 253.60 \\
Model 3 & 216.84 & 107.78 & 428.03 & 9.82 & 271.05 \\
Model 4 & 89.97 & 61.19 & 131.92 & 4.07 & 112.46 \\
Model 5 & 90.59 & 60.77 & 136.53 & 4.10 & 113.24 \\
Model 6 & 103.25 & 67.97 & 155.92 & 4.68 & 129.06 \\
\hline
\end{tabular}

Notes: 95\% CI is derived using the Krinsky and Robb (1986) procedure (using 5,000 simulations). The reported median household income is C $\$ 2,208.48$, and the median expenditure on tap water is $C \$ 80.00$. 
Table 5. Tests of median WTP differences

Probabilities of significant differences

Hypotheses

in median WTP based on raw and recoded votes

$\begin{array}{ll}\mathrm{P}\left(\mathrm{WTP}_{\text {Model 1 }}>\mathrm{WTP}_{\text {Model 4 }}\right) & 0.978554 \\ \left.\mathrm{P}_{\mathrm{WTP}} \text { Model 2 }>\mathrm{WTP}_{\text {Model 5 }}\right) & 0.976366 \\ \mathrm{P}\left(\mathrm{WTP}_{\text {Model 3 }}>\mathrm{WTP}_{\text {Model 6 }}\right) & 0.963169\end{array}$

household income. More conservative WTP estimates are obtained from Models 4 through 6, which take into account the (un)certainty of responses to the referendum voting question (Blumenschein et al., 2008; Morrison and Brown, 2009). These estimates indicate that households would pay an increment of at least C\$90 (US\$4.41), more than 4 per cent of reported median household income which, combined with current tap water expenditures, is above an affordability threshold of 3 per cent of household income suggested by international organizations (see OECD, 2003). This increment is equivalent to more than 112 per cent above the current median water bill.

Conservative WTP estimates were formally compared against the median WTP computed using raw responses to the voting question based on the complete combinatorial approach suggested by Poe et al. (2005). Caparros et al. (2008), Carlsson et al. (2007) and Vásquez et al. (2009) are examples of recent applications of Poe et al.'s (2005) combinatorial approach to test for statistical significance of difference across distributions of $\mathrm{CV}$ responses. This approach yields probabilities that are analogous to conventional $p$ values for hypothesis testing. Table 5 presents computed probabilities that WTP estimates based on raw responses to the referendum question are greater than conservative WTP measures obtained by correcting referendum votes according to response certainty. Correcting vote responses for certainty provides more conservative and presumably realistic estimates of WTP that are significantly smaller than estimates based on raw data (at 5 per cent level).

\section{Discussion and conclusions}

In this paper, household preferences for improved water services and further decentralization at the municipal level are investigated using empirical choice models and the CV method. The study site, Matiguás, has an unreliable water system which provides water that is not always safe to drink. This is a common characteristic of water systems in many urban cities in developing countries (Strand and Walker, 2005; UNDP, 2006). Under these circumstances, improved understanding of household preferences can help identify pricing, affordability and equity challenges and thus help design public policies aimed at improving water services (Griffin and Mjelde, 2000). Furthermore, this study shows that the analysis of local preferences can prove useful in identifying the degree of decentralization that can be most effective in achieving the preferred level of public services. 
Based on conservative estimates obtained through certainty correction, findings indicate that households are willing to pay a significant increment (112-271 per cent) above their current water bills for reliable and safe water services. Soto Montes de Oca and Bateman (2006) note that earlier CV studies conducted in Asian and African urban communities report WTP for an improved water supply system between 50 and 340 per cent of existing water bills. The estimated WTP of Matiguás' residents presented in this study lie within that range. Equivalent to more than 4 per cent of reported median household income, estimates of Matiguás' residents' WTP for improved water services are also comparable to WTP estimates presented in earlier CV studies (e.g., Vásquez et al., 2009), but above a suggested affordability threshold of 3 per cent of household income (OECD, 2003). Current household expenditures on water may already be above that threshold if private investments in water infrastructure, costs of averting measures (e.g., water boiling and filtering), consumption of bottled water and costs associated with water-borne diseases (e.g., work days lost and resources spent on health care) are taken into account. Estimating these household expenditures may provide evidence of the affordability of improved water services. As another point of comparison, based on a number of hedonic housing price models, Nauges et al. (2008) estimate that real household income increases by 1 per cent to 5 per cent when initially unconnected households obtain access to tap water in urban areas of El Salvador and Guatemala.

While the evidence presented here points to the latent demand for improved water services, households do not seem to have strong preferences for (or against) actual decentralization initiatives. WTP models show that households are indifferent among different decentralization levels (current departmental administration vs. further decentralization to the municipal level). Choice models, however, provide further information on household preferences for decentralization levels and suggest that households slightly favor current departmental services (over further decentralization to the municipal level) in terms of expected service quality, knowledge of water problems and capacity to solve them. Interestingly, households tend to believe that the municipality would show more interest in improving water services than the current departmental administration. Satisfaction from current water services is the primary determinant of such household beliefs.

At first glance, choice models and the CV method may seem to yield contradictory results regarding local preferences for decentralization. However, the local indifference on decentralization initiatives is consistent with household preferences stated through choice questions that favor the actual departmental administration based on some institutional characteristics (i.e., service quality, knowledge and capacity), but favor the municipality based on the institution's interest in solving water issues in the city. In addition, the majority preferring a given institution is not overwhelming in any case, and indeed is statistically insignificant for potential investments in water infrastructure, which can be captured by the unwillingness to pay more for further decentralization. 
Another possible explanation for this result is that, while choice questions only varied a single attribute of water services (i.e., the provider), the CV scenario also varies the reliability of the system, water quality and, more importantly, the water fee. In a context of high poverty as in Matiguás, households may focus more on the cost of improved water services than on the decentralization initiative (see Carlsson et al. (2007) for an extensive discussion of the effects of prices on stated preferences).

For policy purposes, our findings suggest that strengthening the managerial and financial capacity of municipalities is needed if water services are to be further decentralized at the municipal level in Nicaragua as considered in the national water strategy (CONAPAS, 2005). This would help the municipality better operate and maintain water systems, but more importantly it may increase public support for such policy implementation. Households perceive a genuine interest in the municipality of Matiguás as a potential actor of solving current water problems, but also point to potential areas that the municipality needs to improve before undertaking any water system administration. The municipality needs to show better knowledge of water problems in the area and the preferred levels of system reliability and water quality. On the latter, this study provides evidence of households' preferences for reliable and safe water services, as well as WTP estimates that can be used to evaluate financial feasibility for such improved services.

\section{References}

Ahmad, J., S. Devarajan, S. Khemani, and S. Shah (2005), 'Decentralization and service delivery', World Bank Policy Research Working Paper 3603, World Bank, Washington, DC.

Anwandter, L. and T. Ozuna (2002), 'Can public sector reforms improve the efficiency of public water utilities?', Environment and Development Economics 7: 687-700.

Arze, F.J. and J. Martinez-Vazquez (2004), 'Descentralización en América Latina desde una perspectiva de países pequeños: Bolivia, El Salvador, Ecuador y Nicaragua', Gestión y Política Pública 13: 619-661 [in Spanish].

Asthana, A. (2003), 'Decentralisation and supply efficiency: the case of rural water supply in Central India', Journal of Development Studies 39: 148-159.

Baisa, B., L. Davis, S. Salant, and W. Wilcox (2010), 'The welfare costs of unreliable water services', Journal of Development Economics 92: 1-12.

Bardhan, P. (2002), 'Decentralization of governance and development', Journal of Economic Perspectives 16: 185-205.

Bardhan, P. and D. Mookhejee (2000), 'Capture and governance at local and national levels', American Economic Review 90: 135-139.

Bingham, L. (2006), 'The new urban governance: processes for engaging citizens and stakeholders', Review of Policy Research 23: 815-826.

Blaurock-Busch, E. (2009), 'Bottled water: better than tap?', The Original Internist 16: 69-74.

Blumenschein, K., G. Blomquist, M. Johannesson, N. Horn, and P. Freeman (2008), 'Eliciting willingness to pay without bias: evidence from a field experiment', Economic Journal 118: 114-137. 
Cameron, T.A. (1988), 'A new paradigm for valuing non-market goods using referendum data: maximum likelihood estimation by censored logistic regression', Journal of Environmental Economics and Management 15: 355-379.

Caparros, A., J.R. Oviedo, and P. Campos (2008), 'Would you choose your preferred option? comparing choice and recoded ranking experiments', American Journal of Agricultural Economics 90: 843-855.

Carlsson, F., P. Frykblom, and C.J. Lagerkvist (2007), 'Preference with and without prices: does the price attribute affect the stated preference surveys?', Environmental and Resource Economics 38: 155-164.

Carson, R.T. and T. Groves (2007), 'Incentive and informational properties of preference questions', Environmental and Resource Economics 37, 181-210.

Carson, R.T. and W.M. Hanemann (2006), 'Contingent valuation', in K.G. Mäler and J.R. Vincent (eds), Handbook of Environmental Economics, Volume 2, North Holland: Elsevier, pp. 821-936.

Casey, J.F., J.R. Kahn, and A. Rivas (2006), ‘Willingness to pay for improved water services in Manaus, Amazonas, Brazil', Ecological Economics 58: 365-372.

Champ, P.A., R.C. Bishop, T.C. Brown, and D.W. McCollum (1997), 'Using donation mechanisms to value nonuse benefits from public goods', Journal of Environmental Economics and Management 33: 151-162.

CONAPAS (2005), 'Estrategia sectorial de agua potable y saneamiento (2005-2015)', Comisión Nacional de Agua Potable y Saneamiento (CONAPAS), Gobierno de Nicaragua, Nicaragua [in Spanish].

Ferrier, C. (2001), 'Bottled water: understanding a social phenomenon', Ambio 30: 118-119.

Goodrich, J., J. Adams, B. Lykins, and R. Clark (1992), 'Safe drinking water from small systems', Journal of the American Water Works Association 84: 49-55.

Griffin, R.C. and J.W. Mjelde (2000), 'Valuing water supply reliability', American Journal of Agricultural Economics 82: 414-426.

Groothuis, P.A., J.D. Groothuis, and J.C. Whitehead (2007), 'The willingness to pay to remove billboards and improve scenic amenities', Journal of Environmental Management 85: 1094-1100.

Herriges, J., C. Kling, C. Liu, and J. Tobias (2010), 'What are the consequences of consequentiality?', Journal of Environmental Economics and Management 59: 67-81.

INIDE (Instituto Nacional de Información de Desarrollo) (2005), VIII Censo de población y IV de vivienda, [Available at] http://www.inide.gob.ni/censos2005/ CifrasMun/Matagalpa/Matiguas.pdf.

Isham, J. and S. Kahkonen (2002), 'Institutional determinants of the impact of community-based water services: evidence from Sri Lanka and India', Economic Development and Cultural Change 50: 667-691.

Krinsky, I. and A.L. Robb (1986), 'On approximating the statistical properties of elasticities', Review of Economics and Statistics 68: 715-719.

Larson, A.M. (2002), 'Natural resources and decentralization in Nicaragua: are local governments up to the job?', World Development 30: 17-31.

Levard, L., Y. Marín López, and I. Navarro (2001), 'Municipio de Matiguás: potenciales y limitantes del desarrollo agropecuario', Cuadernos de Investigación, No. 11, Managua [in Spanish].

Morrison, M. and T.C. Brown (2009), 'Testing the effectiveness of certainty scales, cheap talk, and dissonance-minimization in reducing hypothetical bias in contingent valuation studies', Environmental and Resource Economics 44: 307-326.

Nauges, C., J. Strand, and I. Walker (2008), 'The value of water connections in Central American cities: a revealed preference study', Environment and Development Economics 14: 349-370. 
OECD (2003), Social Issues in the Provision and Pricing of Water Services, Paris: OECD Publishing.

Olmstead, S. (2003), 'Water supply and poor communities: what's price got to do with it?', Environment 45: 22-35.

PAHO and ENACAL (2004), Analisis Sectorial de Agua Potable y Saneamiento de Nicaragua, Nicaragua: Panamerican Health Organization (PAHO) and Empresa Nacional de Acueductos y Alcantarillados (ENACAL) [in Spanish].

Pattanayak, S.K., J.C. Yang, D. Whittington, and K.C. Bal Kumar (2005), 'Coping with unreliable public water supplies: averting expenditures by households in Kathmandu, Nepal', Water Resources Research 41, W02012; doi:10.1029/ 2003 WR002443.

Poe, G.L., K.L. Giraud, and J.B. Loomis (2005), 'Computational methods for measuring the difference of empirical distributions', American Journal of Agricultural Economics 87: 353-366.

Prasad, N. (2006), 'Privatisation results: private sector participation in water services after 15 years', Development Policy Review 24: 669-692.

Prüss-Üstün, A., D. Kay, L. Fewtrell, and J. Bartram (2004), ‘Unsafe water, sanitation and hygiene', in M. Ezzati, A.D. Lopez, A. Rodgers and C.J.L. Murray (eds), Global and Regional Burden of Diseases Attributable to Selected Major Risk Factors, Geneva: World Health Organization.

Rodriguez-Pose, A., S.A. Tijmstra, and A. Bwire (2009), Fiscal decentralisation, efficiency, and growth', Environment and Planning A 41: 2041-2062.

Rojas, F. (2000), 'The political context of decentralization in Latin America: accounting for the particular demands of decentralization in the region', in S.J. Burki and G.E. Perry (eds), Annual World Bank Conference on Development in Latin America and the Caribbean, Washington, DC: World Bank.

Rosado, M.A., M.A. Cunha-e-sá, M. Ducla-Soares, and L.C. Nunes (2006), ‘Combining averting behavior and contingent valuation data: an application to drinking water treatment in Brazil', Environment and Development Economics 11: 729-746.

Rosales, M. and S. Valencia Carmona (2008), 'Latin America', in Decentralization and Local Democracy in the World, Barcelona: United Cities and Local Governments and World Bank.

Rouse, M. (2007), Institutional Governance and Regulation of Water Services: The Essential Elements, London: IWA Publishing.

Soto Montes de Oca, G. and I.J. Bateman (2006), 'Scope sensitivity in households' willingness to pay for maintained and improved water supplies in a developing world urban area: investigating the influence of baseline supply quality and income distribution upon stated preferences in Mexico City', Water Resources Research 42, W07421; doi:10.1029/2005WR003981.

Strand, J. and I. Walker (2005), 'Water markets and demand in Central American cities', Environment and Development Economics 10: 313-335.

UNDP (2006), Human Development Report, New York: United Nations Development Program.

Van Hecken, G. and J. Bastiaensen (2009), 'The potential and limitations of markets and payments for ecosystem services in protecting the environment: critical reflections inspired by an assessment of the RISEMP program in Matiguás-Río Blanco, Nicaragua', IDPM-UA Discussion Paper 2009-02, Institute of Development Policy and Management, Antwerp.

Vásquez, W.F., P. Mozumder, J. Hernández Arce, and R.P. Berrens (2009), 'Willingness to pay for safe drinking water: evidence from Parral, Mexico', Journal of Environmental Management 90: 3391-3400.

Vossler, C.A., R.G. Ethier, G.L. Poe, and M.P. Welsh (2003), 'Payment certainty in discrete choice contingent valuation responses: results from a field validity test', Southern Economic Journal 69: 886-902. 
Whitehead, J.C. (1995), 'Willingness to pay for quality improvements: comparative statics and interpretation of contingent valuation results', Land Economics 71: 207-215.

Whittington, D. (1998), 'Administering contingent valuation surveys in developing countries', World Development 26: 21-30.

Whittington, D. (2002), 'Improving the performance of contingent valuation studies in developing countries', Environmental and Resource Economics 22: 323-367.

Whittington, D. (2004), 'Ethical issues with contingent valuation surveys in developing countries: a note on informed consent and other concerns', Environmental and Resource Economics 28: 507-515.

World Bank (1993), 'The demand for water in rural areas: determinants and policy implications', World Bank Research Observer 8: 47-70.

World Bank (2003), World Development Report 2004: Making Services Work for the Poor People, Washington, DC: World Bank and Oxford University Press.

World Bank (2008), Nicaragua: Informe sobre la Pobreza 1993-2005, Informe No. 39736NI, Washington DC: World Bank. 